Article

\title{
Nomad Jellyfish Rhopilema nomadica Venom Induces Apoptotic Cell Death and Cell Cycle Arrest in Human Hepatocellular Carcinoma HepG2 Cells
}

\author{
Mohamed M. Tawfik ${ }^{1, *} \mathbb{(}$, Nourhan Eissa ${ }^{1}\left[\right.$, Fayez Althobaiti ${ }^{2}$, Eman Fayad ${ }^{2, *}$ ) and Ali H. Abu Almaaty ${ }^{1}$ \\ 1 Department of Zoology, Faculty of Science, Port Said University, Port Said 42526, Egypt; \\ n.essa@sci.psu.edu.eg (N.E.); ali_hussein@sci.psu.edu.eg (A.H.A.A.) \\ 2 Department of Biotechnology, Faculty of Sciences, Taif University, P.O. Box 11099, Taif 21944, Saudi Arabia; \\ faiz@tu.edu.sa \\ * Correspondence: tawfik@sci.psu.edu.eg (M.M.T.); e.esmail@tu.edu.sa (E.F.)
}

\section{check for} updates

Citation: Tawfik, M.M.; Eissa, N.; Althobaiti, F.; Fayad, E.; Abu Almaaty, A.H. Nomad Jellyfish Rhopilema nomadica Venom Induces Apoptotic Cell Death and Cell Cycle Arrest in Human Hepatocellular Carcinoma HepG2 Cells. Molecules 2021, 26, 5185. https://doi.org/10.3390/molecules 26175185

Academic Editors: Višnja Stepanić and Marta Kučerová-Chlupáčová

Received: 30 June 2021

Accepted: 17 August 2021

Published: 26 August 2021

Publisher's Note: MDPI stays neutral with regard to jurisdictional claims in published maps and institutional affiliations.

Copyright: (c) 2021 by the authors. Licensee MDPI, Basel, Switzerland. This article is an open access article distributed under the terms and conditions of the Creative Commons Attribution (CC BY) license (https:/ / creativecommons.org/licenses/by/ $4.0 /)$.

\begin{abstract}
Jellyfish venom is a rich source of bioactive proteins and peptides with various biological activities including antioxidant, antimicrobial and antitumor effects. However, the anti-proliferative activity of the crude extract of Rhopilema nomadica jellyfish venom has not been examined yet. The present study aimed at the investigation of the in vitro effect of $R$. nomadica venom on liver cancer cells (HepG2), breast cancer cells (MDA-MB231), human normal fibroblast (HFB4), and human normal lung cells (WI-38) proliferation by using MTT assay. The apoptotic cell death in HepG2 cells was investigated using Annexin V-FITC/PI double staining-based flow cytometry analysis, western blot analysis, and DNA fragmentation assays. $R$. nomadica venom displayed significant dose-dependent cytotoxicity on HepG2 cells after $48 \mathrm{~h}$ of treatment with $\mathrm{IC}_{50}$ value of $50 \mu \mathrm{g} / \mathrm{mL}$ and higher toxicity (3:5-fold change) against MDA-MB231, HFB4, and WI-38 cells. R. nomadica venom showed a prominent increase of apoptosis as revealed by cell cycle arrest at G2/M phase, upregulation of $\mathrm{p} 53, \mathrm{BAX}$, and caspase- 3 proteins, and the down-regulation of anti-apoptotic Bcl-2 protein and DNA fragmentation. These findings suggest that $R$. nomadica venom induces apoptosis in hepatocellular carcinoma cells. To the best of the authors' knowledge, this is the first scientific evidence demonstrating the induction of apoptosis and cell cycle arrest of $R$. nomadica jellyfish venom.
\end{abstract}

Keywords: Rhopilema nomadica; apoptosis; cell cycle arrest; HepG2

\section{Introduction}

Hepatocellular carcinoma (HCC) is the fourth most common cause of cancer-related mortality globally [1]. In Egypt, HCC is one of the prevalent malignancy cancer accounting for $70.48 \%$ of all liver tumors in both sexes, which may be attributed to the rising incidence rates of hepatitis $C$ virus-related cirrhosis $[2,3]$. Chemotherapy and radiotherapy were determined to be the main rational therapeutic regimens for HCC [4,5]. However, the use of these routine treatments is assigned with potent toxic adverse effects in addition to the development of resistance of HCC cells to anticancer drugs [6,7]. In this perspective, there is an unmet need for novel anticancer agents that may have different mechanisms of action from current therapies, leading to higher selectivity for HCC cells.

Recently, jellyfish populations are rapidly increasing in various marine ecosystems worldwide, which may be associated with global warming, eutrophication, alien species invasions, and changes in salinity [8-10]. Jellyfish venom is primarily confined in specialized venom-containing capsules known as nematocysts that are found mainly in the tentacles. Nematocysts venom contains a mixture of bioactive proteins and peptides, which exhibits hemolytic, cardiotoxic, neurotoxic, musculotoxic, antioxidant, and cytolytic effects [11-15]. Jellyfish venom proteins are highly potent against a panel of human cancer cell lines which have attracted significant interests in tumor research [16,17]. 
Stimulating apoptotic pathways is the most significant non-surgical cancer treatment and HCC treatment in particular. Such strategies to trigger cancer cell death include upregulation of pro-apoptotic proteins and reduction of the expression of anti-apoptotic proteins [18-20]. Apoptosis is mainly associated with DNA fragmentation, chromatin compaction, nuclear fragmentation, and cell cycle arrest [21-23]. Interestingly, various jellyfish venoms have been reported to induce apoptosis and cell cycle arrest against diverse cancer cells [24,25]. Several studies have clearly indicated the link between the ability of jellyfish venom to produce oxidative stress and its induction of apoptosis in cancer cells $[16,26,27]$. ROS generation, lipid peroxidation induction, and mitochondria damage contribute to the cytotoxicity of the particular jellyfish venom, e.g., that of Pelagia noctiluca towards colon cancer cells and that of Cassiopea andromeda towards breast cancer cells, respectively $[28,29]$.

Rhopilema nomadica jellyfish (nomad jellyfish) blooms off the eastern Mediterranean coasts of Italy, Turkey, Greece, Tunisia, and Egypt [30-32]. Nomad jellyfish was introduced in the Egyptian Mediterranean via Suez Canal in the latter half of the last century, which causes severe damage effects on the fishery industry and tourism $[33,34]$. Very few studies have explored the biological activities of nomad jellyfish. The present study is designed to assess the cytotoxic activity of $R$. nomadica venom on liver cancer cells (HepG2), breast cancer cells (MDA-MB231), human normal fibroblast (HFB4), and human normal lung cells (WI-38). The study also evaluates the extent of apoptosis in HepG2 cell death caused by $R$. nomadica venom.

\section{Results}

\subsection{Electrophoretic Separation of the Protein Mixture of R. nomadica Venom by SDS-PAGE}

Quantitative analysis of proteins from $R$. nomadica venom was performed using the SDS-PAGE gel. The results revealed the presence of proteins ranging in mass from 16 to $\sim 250 \mathrm{kDa}$. Major six protein bands with molecular masses of $\sim 16, \sim 18, \sim 23, \sim 28, \sim 31$, and $\sim 48 \mathrm{kDa}$ have dominated the profile (Figure 1).

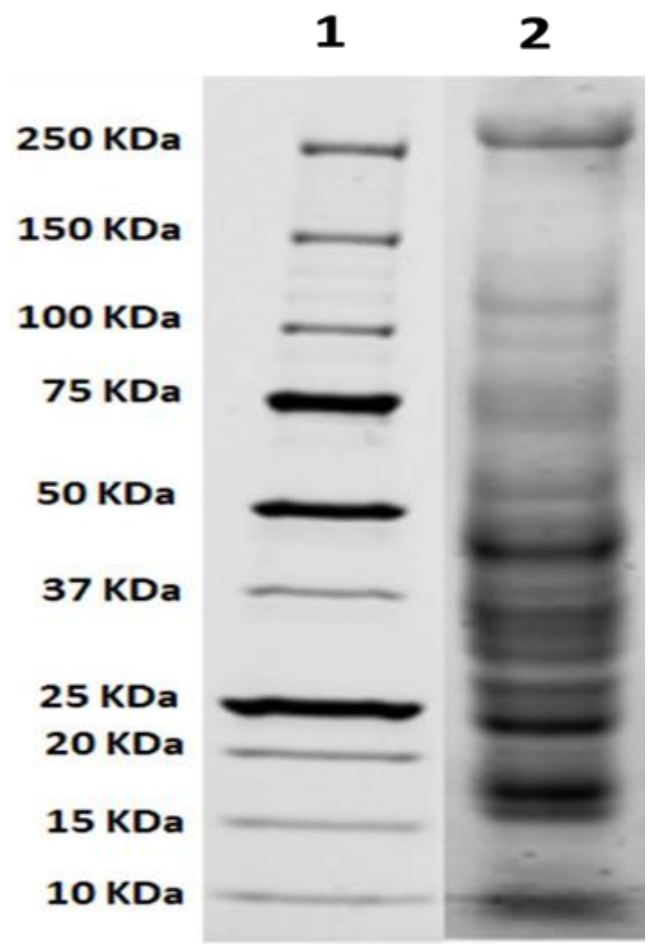

Figure 1. SDS-PAGE protein profile of R. nomadica venom. Lane 1: standard marker, Lane 2: protein extracts from the crude venom. 


\subsection{R. nomadica Venom Suppresses the Growth of HepG2, MDA-MB231, HFB4 and WI-38 Cells}

$R$. nomadica venom was evaluated for cytotoxic activity on the viability of the human hepatocellular carcinoma cell line (HepG2) using MTT assay. The venom has shown a significant cytotoxic effect on HepG2 cells in a concentration-dependent manner after $48 \mathrm{~h}$ of cell treatment. The $\mathrm{IC}_{50}$ value was approximately determined to be $50 \mu \mathrm{g} / \mathrm{mL}$.

The toxicity testing of the venom was extended on extra cancer cell line MDA-MB231 (breast cancer) and two normal cell lines HFB4 (human fibroblast) and WI-38 (human lung cells). Results showed that MDA-MB231, WI-38, and HFB4 cells had an $\mathrm{IC}_{50}$ for the venom of 216, 250, and $168 \mu \mathrm{g} / \mathrm{mL}$, respectively, 3:5-fold higher than HepG2 cells. Therefore, the crude extract of $R$. nomadica venom exhibited some preference against HepG2 cells rather than other cancer or normal cell lines (Figure 2).

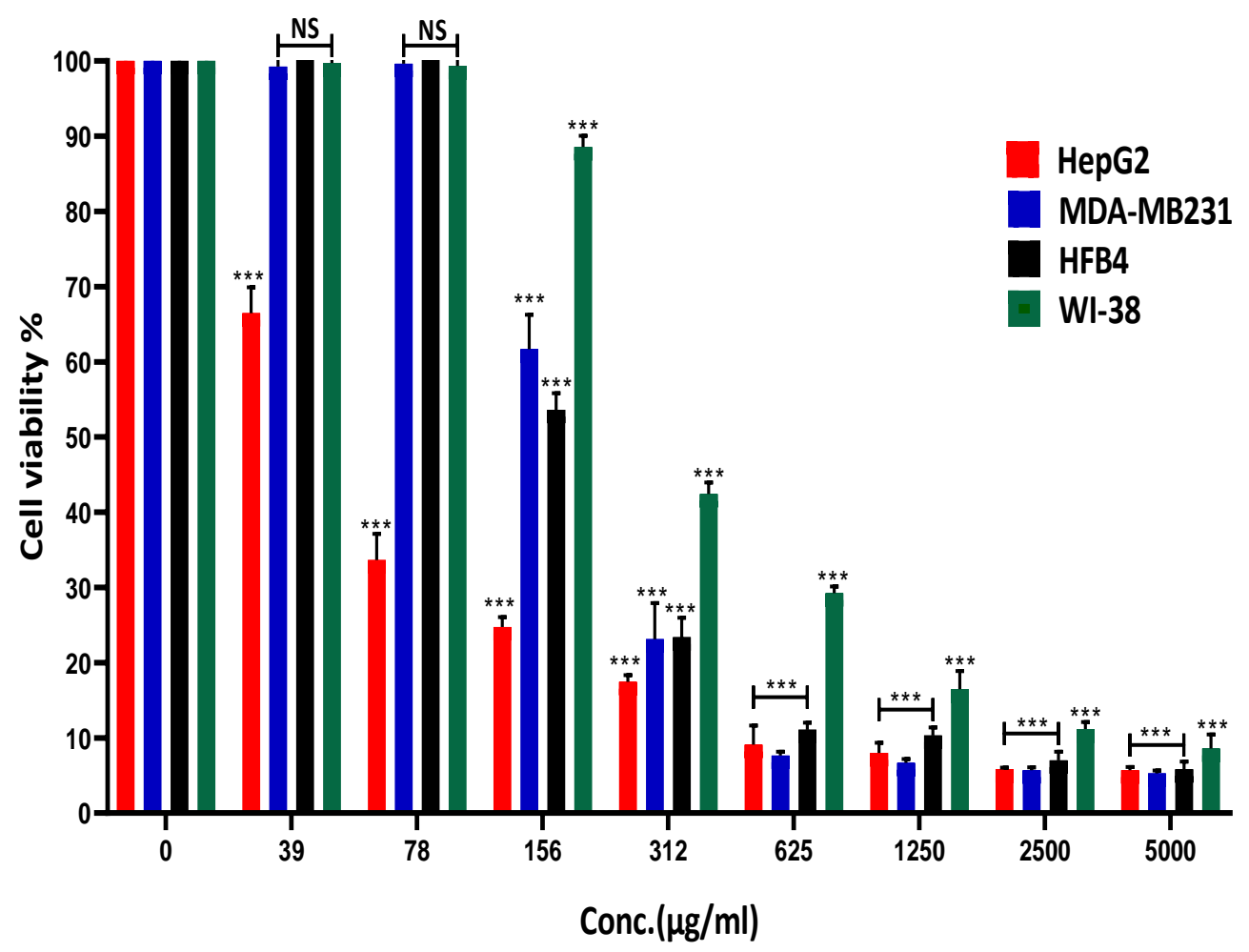

Figure 2. Effects of R. nomadica venom on cell proliferation of HepG2, MDA-MB231, HFB4, and WI-38 cell lines at different concentrations. The percentage of cell viability was measured using MTT assay after $48 \mathrm{~h}$ treatment. Non-treated cells were used as a control. Data are analyzed with one-way ANOVA followed by Tukey's test. All values are represented as mean \pm SEM. ${ }^{* * *}$ denotes significance difference $(p<0.001)$ vs. control, otherwise noted NS: non-significant $(p>0.05)$.

\subsection{R. nomadica Venom Induces G2/M Arrest on HepG2 Cells}

Flow cytometric analysis of the cell cycle was performed to determine the cell cycle distribution of HepG2 cells treated with $R$. nomadica venom. The incubation of HepG2 cells with $\mathrm{IC}_{50}$ of $R$. nomadica venom for $48 \mathrm{~h}$ caused cell cycle arrest at the G2/M phase. The population of cells in G2/M and sub-G1 phases significantly increased from $12.28 \%$ and $1.49 \%$ in untreated cells to $28.51 \%$ and $18.17 \%$ in the treated cells with $R$. nomadica venom, respectively $(p<0.001)$. On the contrary, the treatment with $R$. nomadica venom resulted in a statistically significant decrease in the population of cells in G0-G1 and S phases $(p<0.001)$ (Figure 3). 

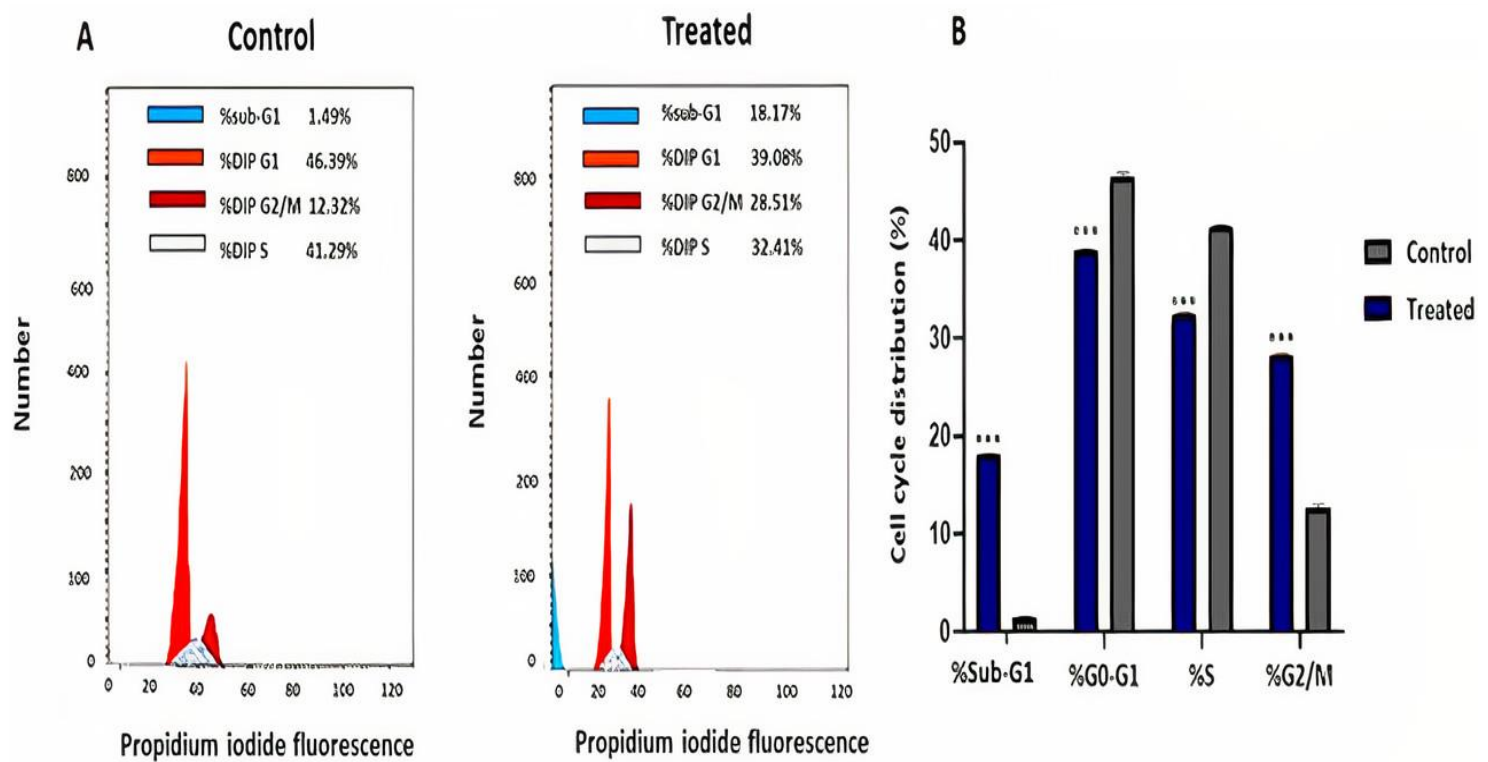

Figure 3. Cell cycle analysis of HepG2 cells treated with $\mathrm{IC}_{50}$ value of $R$. nomadica venom for $48 \mathrm{~h}$ by flow cytometry. (A) Representative profiles of cell cycle distribution in HepG2 cells after treatments. (B) The percentages of cell populations in sub-G1, G0-G1, S and G2/M phases. Data are analyzed with paired Student's t-test. Values are represented as mean \pm SEM. ${ }^{* * *}$ denotes significance difference $(p<0.001)$ vs. control.

\subsection{R. nomadica Venom Induces Apoptosis in HepG2 Cells}

Annexin V-FITC/PI double staining-dependent on flow cytometry analysis showed that R. nomadica venom-induced apoptotic cell death in HepG2 cells (Figure 4). Populations of early and late apoptotic cells were significantly increased after $48 \mathrm{~h}$ treatment of $\mathrm{IC}_{50}$ of $R$. nomadica venom compared to untreated HepG2 cells $(p<0.001)$. Accordingly, the percentage of total apoptotic cells was significantly increased from $1.49 \%$ to $18.17 \%$ of treated cells.

A

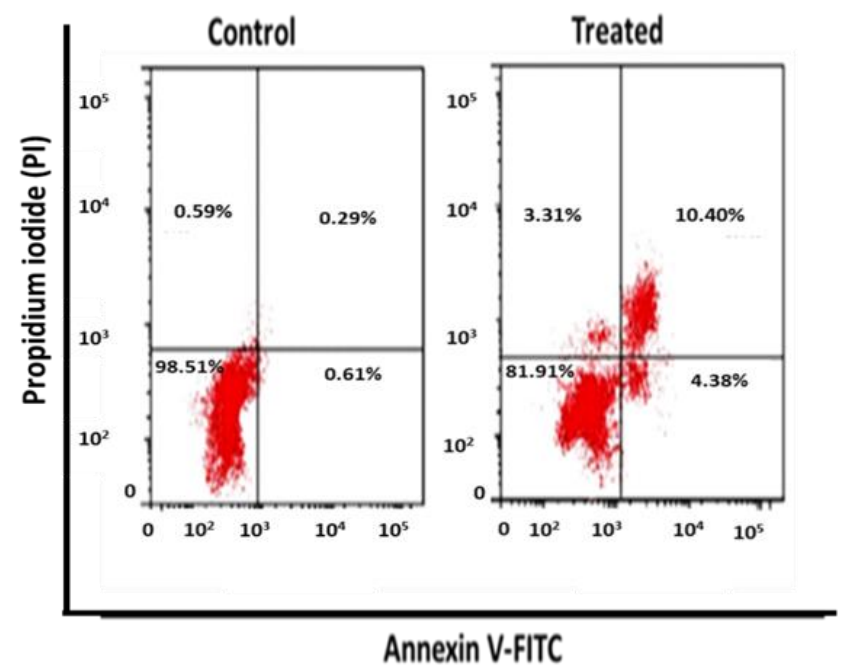

B

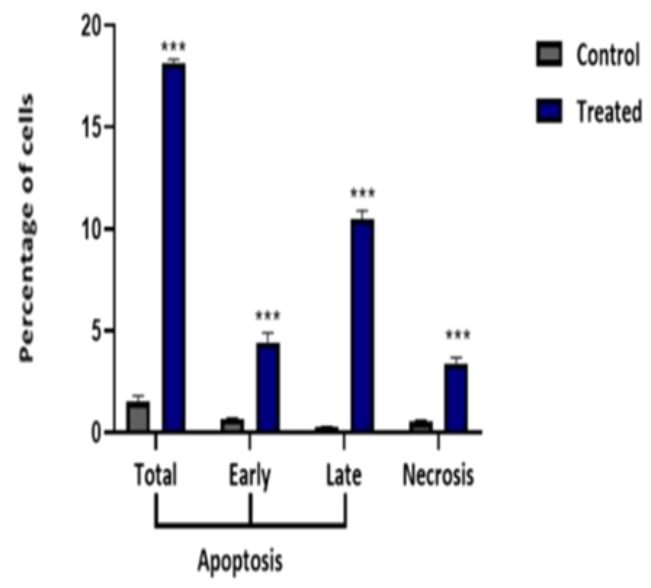

Figure 4. Apoptosis detection assay was performed using the Annexin V/PI double staining assay in HepG2 cells. HepG2 cells were treated with $\mathrm{IC}_{50}$ value of $R$. nomadica venom for $48 \mathrm{~h}$, stained with Annexin V and PI, and analyzed on BD FACSCalibur flow cytometer. (A) Representative scatter plots of PI ( $y$-axis) vs. Annexin V ( $x$-axis). Lower left quadrants show viable cells (An -, PI -), whereas lower right quadrants represent the early apoptotic cells (An,+ PI -). The upper left quadrants contain the necrotic cells (An -, PI +), while the upper right quadrants demonstrate the late apoptotic cells (An +, PI +). (B) Quantification graph of Annexin V/PI double staining assay obtained from BD FACSCalibur flow cytometer. Data are analyzed with paired Student's t-test. Values are represented as mean $\pm \mathrm{SEM}$. ${ }^{* * *}$ denotes significance difference $(p<0.001)$ vs. control. 


\subsection{R. nomadica Venom Induces Apoptosis in HepG2 Cells through the Regulation of the Expression of Apoptosis-Related Proteins}

To understand the molecular mechanisms underlying $R$. nomadica venom-induced apoptosis, western blotting was performed to investigate the expression levels of apoptosisrelated proteins. The expression of anti-apoptotic Bcl-2 protein was remarkably decreased in R. nomadica venom-treated HepG2 cells after $48 \mathrm{~h}$ treatment with $\mathrm{IC}_{50}$ concentration. Whereas apoptosis-inducing proteins BAX, caspase-3, and p53 were increased in the treated cells. Upon treatment of HepG2 cells with $R$. nomadica venom, a significant increase in Bax/Bcl-2 ratio compared to untreated cells $(p<0.01)$ (Figure 5).
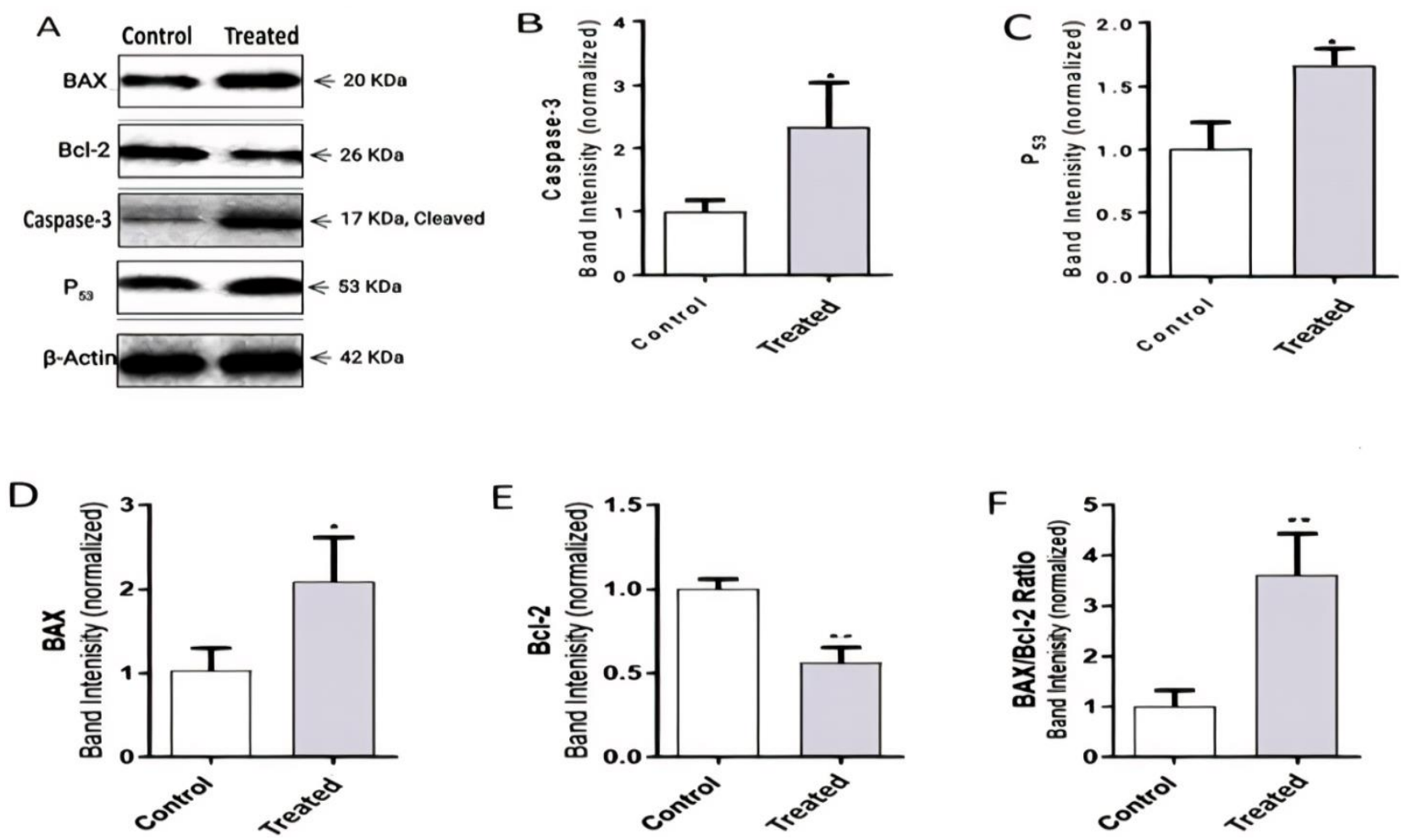

Figure 5. Western blot analysis. (A) shows western blot results about the expression level of apoptosis-related proteins BAX, Bcl-2, caspase-3, and p53 in HepG2 cells after being treated for $48 \mathrm{~h}$ with $\mathrm{IC}_{50}$ concentration of $R$. nomadica venom. From (B-F) represent the statistical graphs of the density ratios of the proteins calculated by ImageLab. Protein levels were normalized to $\beta$-Actin. Data are analyzed with paired Student's t-test Values are represented as mean $\pm \mathrm{SEM}$. ${ }^{*}$ denotes significance difference $(p<0.05)$ vs. control. ${ }^{* *}$ denotes significance $(p<0.01)$ vs. control.

\subsection{R. nomadica Venom Induces DNA Damage}

The DPA assay measured the relative quantity of DNA fragments in the treated HepG2 cells with $R$. nomadica venom (Figure 6). Compared to the untreated cells (5.27\% $\pm 0.29 \%)$, $R$. nomadica venom at concentrations of 25 and $50 \mu \mathrm{g} / \mathrm{mL}$ caused a marked significant elevation in DNA fragmentation percentage $(30.47 \% \pm 1.66 \%)$ and $(42.85 \% \pm 2.33 \%)$, respectively.

Agarose gel electrophoresis of DNA from HepG2 cells treated with R. nomadica venom showed a ladder-like pattern of DNA fragments in a concentration-dependent manner relative to untreated cells (Figure 7). The gel pattern of the DNA samples isolated from untreated control of HepG2 cells showed clear bands of intact DNA, while R. nomadica venom-induced an increase in DNA smearing level with increasing dose from 25 to $50 \mu \mathrm{g} / \mathrm{mL}$. 


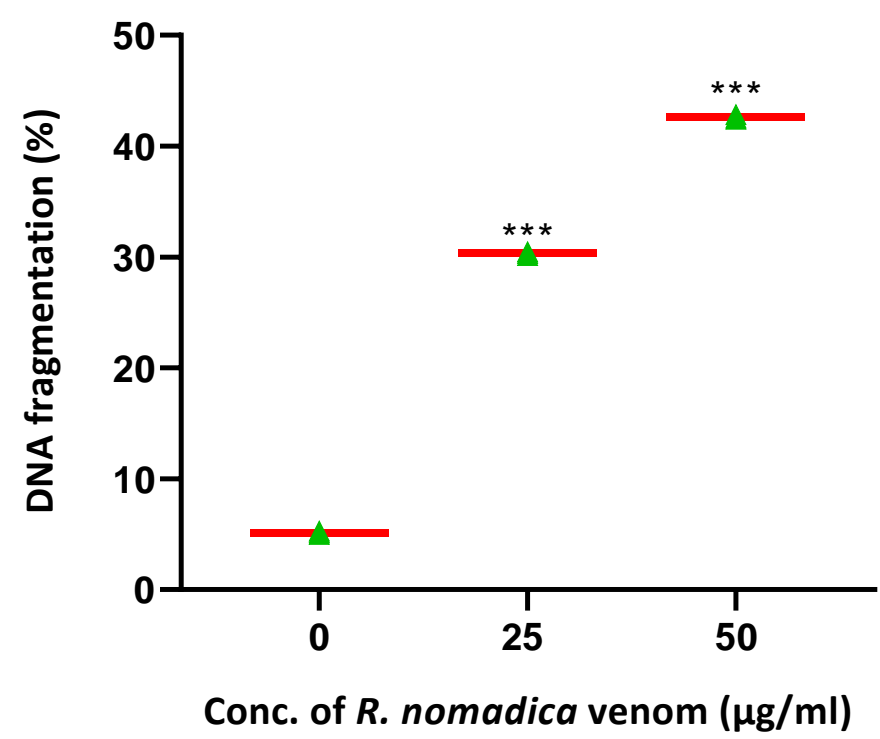

Figure 6. Quantitative estimation of DNA fragmentation by diphenylamine (DPA) assay in treated HepG2 cells with two different concentrations of $R$. nomadica venom $(25-50 \mu \mathrm{g} / \mathrm{mL})$ and untreated cells. Data are analyzed with one-way ANOVA followed by Tukey's test. Values are represented as mean \pm SEM. ${ }^{* * *}$ denotes significance difference $(p<0.001)$ vs. control.

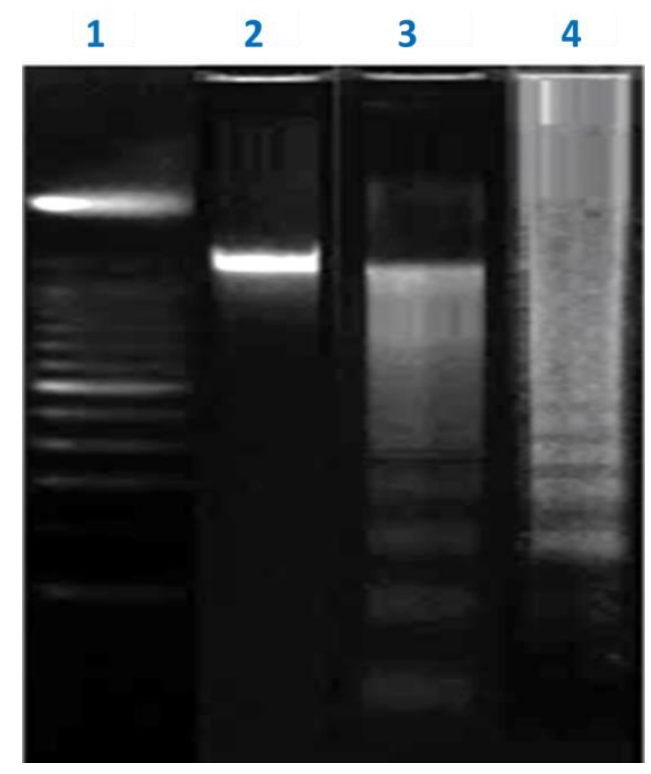

Figure 7. Electrophoretic pattern of DNA fragments isolated from HepG2 cells on $8 \%$ agarose gel electrophoresis. Lane 1: DNA marker, 100-bp. Lane 2: the intact DNA of the untreated HepG2 cells. Lane 3 and 4: the fragmented DNA of HepG2 cells treated with 25 and $50 \mu \mathrm{g} / \mathrm{mL}$ of $R$. nomadica venom, respectively.

\subsection{R. nomadica Venom Induces Less Hemolytic Activity against Human Erythrocytes}

The hemolysis assay is carried out to investigate whether the cytotoxic activity is related to direct damage to the cell membrane. $R$. nomadica venom exhibited weak hemolytic activity under $10 \%$ at tested concentrations from 40 to $640 \mu \mathrm{g} / \mathrm{mL}$ (Figure 8). 


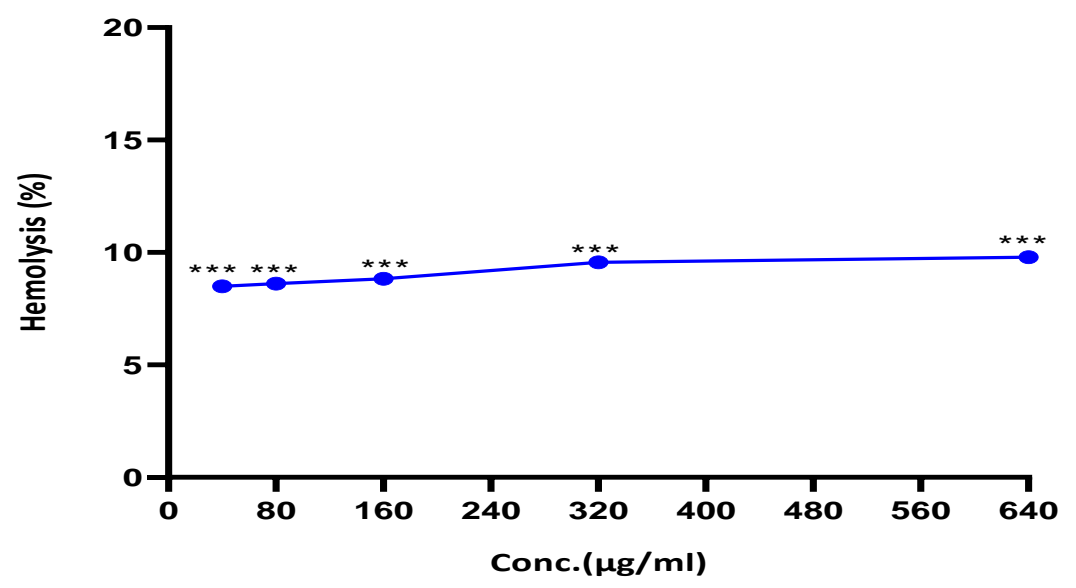

Figure 8. The hemolytic activity of $R$. nomadica venom against human $\mathrm{RBC}_{\mathrm{s}}$ incubated with serial concentrations of the crude venom for $1 \mathrm{~h}$ at room temperature. PBS and 10\% triton $100 \times$ were used as negative and positive controls, respectively. The absorbance of the supernatant was measured at $570 \mathrm{~nm}$. Data are analyzed with one-way ANOVA followed by Tukey's test. Values are represented as mean \pm SEM. ${ }^{* * *}$ denotes significance difference $(p<0.001)$ vs. control.

\section{Discussion}

Jellyfish venoms have long attracted the interest of researchers to find and develop novel anticancer agents. Jellyfish venoms either or isolated peptides have anti-proliferative effects on various cancer cell lines such as brain, colorectal, breast, lung, and liver cancer cells $[26,28,35-37]$. Although there are many swarms of $R$. nomadica jellyfish in the summertime of the Egyptian Mediterranean coasts, much less attention has been paid to their biological activities. The present study showed that crude venom of $R$. nomadica jellyfish inhibited the growth of HepG2 cells in a dose-dependent manner $\left(\mathrm{IC}_{50}\right.$ value of $50 \mu \mathrm{g} / \mathrm{mL}$ ). Less or no hemolytic activity has been detected for R. nomadica venom against human erythrocytes up to 10 -fold greater than the $\mathrm{IC}_{50}$ concentration. To our knowledge, the anticancer activity of this venom is being reported herein for the first time.

Similar inhibitory effects against HepG2 cells have been reported for other jellyfish species such as Nemopilema nomurai, Cyanea lamarckii, and Acromitus flagellates venoms [35,37-40]. Interestingly, both Acromitus flagellates venom and Cyanea lamarckii extract share three to six protein bands with $R$. nomadica venom in their electrophoretic patterns [35,39]. A pore-forming toxin, CcTX-1 $(31.17 \mathrm{KDa})$, is an isolated proteinaceous cytotoxin from Cyanea capillata jellyfish venom that exhibited potent inhibitory activity against HepG2 cells [41,42]. The other two cytotoxic proteins, known as CfTX-A ( 40 kDa) and CfTX-B ( 42 kDa), were partially purified from Chironex fleckeri venom [43]. Similar protein bands with a similar molecular weight of CcTX-1, CfTX-A, and CfTX-B have been observed in the protein profile of $R$. nomadica venom. These latter findings may interpret the cytotoxic properties of $R$. nomadica venom against HepG2 Cells.

In the current study, the DNA fragmentation assays revealed that treated HepG2 cells with $\mathrm{IC}_{50}$ value of $R$. nomadica venom showed a highly significant DNA fragmentation in comparison to non-treated cells. Similar DNA damages have been observed for Nemopilema nomurai, Chiropsalmus quadrumanus crude venoms and Chrysaora Quinquecirrha venom peptide against a variety of cancer cells particularly HCC cells $[37,44,45]$.

Besides the DNA damage, cell cycle arrest is also a key event in apoptosis. Our results showed the induction of cell cycle arrest at the G2/M phase after the treatment of HepG2 cells for $48 \mathrm{~h}$ with $\mathrm{IC}_{50}$ value of $R$. nomadica venom and elevation in the subG1 population. These data are in accordance with the previous study that exhibited the increase of sub-G1 population in HepG2 cells treated with Nemopilema nomurai venom [37]. DNA fragmentation and cell cycle arrest results were denoting the strong apoptotic effect of $R$. nomadica venom. 
Annexin V and PI double staining assay elucidated the efficacy of R. nomadica venom on triggering apoptosis in HepG2 cells treated with $\mathrm{IC}_{50}$ by raising the percentage of early and late apoptotic cells compared to untreated cells. Similar reports presented the venom potency of different jellyfish species such as Stomolophus nomurai, Chrysaora helvola, Chiropsalmus quadrigatus, Chrysaora Quinquecirrha, and Cassiopea andromeda in inducing the apoptotic cell death in various cancer cells via the formation of apoptotic bodies [36,44-47].

Apoptosis regulation is an impressive target for HCC treatment. Apoptosis is a significant mode of programmed cell death characterized by distinct hallmarks and controlled by essential extrinsic and intrinsic regulatory proteins [48,49]. The intrinsic pathway is mediated by pro-apoptotic proteins such as BAX/BAK proteins and anti-apoptotic proteins involved Bcl-2 and Bcl-xL proteins [50,51]. Terminally, apoptosis is executed by caspaseactivated cascade involved the effector caspases such as caspase-3, 6, 7, and 10, which induce the activation of cytoplasmic endonuclease (CAD), which in turn causes chromatin condensation, DNA fragmentation, the formation of cytoplasmic blebs, and apoptotic bodies [52-54]. Furthermore, p53 is a tumor suppressor protein. Under Extra and intracellular stress signals, it plays a pivotal role in suppressing anti-apoptotic Bcl-2 family proteins. Moreover, p53 can directly interact with BAX and promotes the release of cytochrome $\mathrm{c}$ via mitochondrial outer membrane permeabilization (MOMP), which upregulates the tumor cells apoptosis [51,55].

Likewise, R. nomadica venom induces a potent intrinsically apoptotic effect on HepG2 cells by increasing p53 expression level, which in turn upregulates BAX (pro-apoptotic protein) and downregulates Bcl-2 (anti-apoptotic protein). We also demonstrate the intrinsic apoptotic pathway induced by $R$. nomadica venom in HepG2 cells through the elevation of $\mathrm{BAX} / \mathrm{Bcl}-2$ ratio leading to triggering of caspase-3 signaling protein, which causes cells destruction and ends up to apoptosis. Following the present results, previous studies have demonstrated the activity of other jellyfish venoms on modulating the apoptotic cell death in cancer cells via executioner and regulatory proteins $[36,40,44-46]$. Similarly, some apoptosis-inducing activities of other jellyfish venoms were attributed to their ability to produce high levels of ROS in different cancer cells, which may point out the potential ROS mediated cytotoxicity of $R$. nomadica venom [27-29].

Most of the jellyfish venoms which exhibited potent anticancer activities have strong hemolytic activities such as Palythoa caribaeorum, Nemopilema nomurai, and Cassiopea xamachana [26,56]. Even Nemopilema nomurai (schyphozoa) showed similar selective anticancer activities of $R$. nomadica venom against HepG2 cells rather than other cancer or normal cell lines [37]. However, erythrocytes were more susceptible to N. nomurai as $>50 \%$ of mammalian RBCs underwent hemolysis at 100-200 $\mu \mathrm{g} / \mathrm{mL}$. In comparison with other jellyfish venoms and scyphozoans, $R$. nomadica showed less (weaker) hemolytic activities against RBCs. Furthermore, severe cytotoxicity on cardiac and skeletal cell lines has been reported for N. nomurai [12].

\section{Materials and Methods}

\subsection{Jellyfish Collection}

$R$. nomadica jellyfish specimens were captured from the eastern Egyptian Mediterranean of Port Said coast during the blooming summer months in 2019. Only tentacles were collected in tanks full of fresh seawater and transported immediately to a laboratory for further preparations.

\subsection{Nematocysts Venom Extraction and Preparation}

Nematocysts were isolated from the excised tentacles as described with slight modification [57]. Briefly, dissected tentacles were submerged in cold seawater at the mass: volume ratio of 1:3 to allow autolysis of the tissues at $4{ }^{\circ} \mathrm{C}$ with gentle swirling for $30 \mathrm{~min}$ every two hours. This process was repeated for 3 days. The nematocysts suspension was filtered through a plankton net to remove tissue debris and centrifuged at 10,000 rpm 
for $30 \mathrm{~min}$ at $4{ }^{\circ} \mathrm{C}$. Then, the resultant supernatant was collected, lyophilized, and stored at $-20^{\circ} \mathrm{C}$.

The crude venom was extracted from freeze-dried nematocysts with a minor modification. In which, $100 \mathrm{mg}$ nematocyst powder was resuspended in $1 \mathrm{~mL}$ of phosphate-buffered saline (PBS, pH 7.4, ${ }^{\circ} \mathrm{C}$ ) and centrifuged at $15,000 \mathrm{rpm}$ for $15 \mathrm{~min}$ at $4{ }^{\circ} \mathrm{C}$ [58]. The supernatant was separated and used as the extracted Rhopilema nomadica venom stock solution for the present study. The stock solution was aliquoted (to avoid freezing and rethawing) and stored at $-20^{\circ} \mathrm{C}$. The protein concentration of the venom was estimated by the Bradford method, and the venom was used based on its protein concentration [59]. In terms of quality control, SDS-PAGE (Sodium dodecyl sulfate-polyacrylamide gel electrophoresis) (Bio-Rad Laboratories, Inc., Hercules, CA, USA) was used regularly to assess the banding pattern of venom proteins. Moreover, $\mathrm{IC}_{50}$ (concentration of the venom required for $50 \%$ inhibition of cell growth) against cell lines has been monitored to check the effectiveness and stability of the venom.

\subsection{SDS-Polyacrylamide Gel Electrophoresis}

R. nomadica crude venom proteins were separated based on their molecular weights by using SDS-PAGE. This technique was carried out using $12 \%$ polyacrylamide gel performed by TGX Stain-Free ${ }^{\mathrm{TM}}$ FastCast ${ }^{\mathrm{TM}}$ Acrylamide Kit (Bio-Rad Laboratories, Inc., Hercules, CA, USA). Briefly, the sample was boiled at $95^{\circ} \mathrm{C}$ for $5 \mathrm{~min}$ with the sample loading buffer (4\% SDS, 10\% 2-mercaptoethanol, 20\% glycerol, $0.004 \%$ bromophenol blue and $0.125 \mathrm{M}$ Tris $\mathrm{HCl}, \mathrm{PH}$ 6.8). The protein sample was electrophoresed for $60 \mathrm{~min}$ at $150 \mathrm{~V}$, using Tris-glycine running buffer. Protein bands were visualized using stain-free technology and Chemi Doc imager (Bio-Rad Laboratories, Inc., Hercules, CA, USA) [60].

\subsection{Cell Culture}

HepG2 (human hepatocellular carcinoma), MDA-MB-231 (human breast adenocarcinoma), HFB4 (human normal fibroblast), and WI-38 (human normal lung) cell lines used in the present study were purchased from Holding company for biological products and vaccines (VACSERA, Giza, Egypt). Cells were maintained as monolayer in culture in complete medium (RPMI-1640 medium supplemented with $2 \mathrm{mM}$ L-glutamine, $10 \%$ heat-inactivated FCS, $100 \mathrm{mg} / \mathrm{mL}$ streptomycin, and $100 \mathrm{U} / \mathrm{mL}$ penicillin) and were incubated at $37^{\circ} \mathrm{C}$ with $5 \% \mathrm{CO} 2$ in a humidified atmosphere.

\subsection{Cell Viability by MTT Assay}

To evaluate the potential cytotoxic effect of the $R$. nomadica venom on cell viability, an MTT (3-(4, 5-methylthiazol-2-yl)-2, 5-diphenyl-tetrazolium bromide) reduction assay was performed [61,62]. HepG2, MDA-MB-231, HFB4, and WI-38 cells (VACSERA, Giza, Egypt) were seeded in a 96-well plate at a concentration of $1.0 \times 10^{4}$ cells/well and incubated at $37^{\circ} \mathrm{C}$ for $24 \mathrm{~h}$ to settle down. The cells were treated for another $48 \mathrm{~h}$ with different concentrations ranging from 0 to $5000 \mu \mathrm{g} / \mathrm{mL}$ of $R$. nomadica venom. $20 \mu \mathrm{L}$ of MTT solution was added to each well and incubated for an additional $3 \mathrm{~h}$ at $37^{\circ} \mathrm{C}$. After the supernatant was removed, dimethyl sulfoxide ( $200 \mu \mathrm{L}$ DMSO) was added to each well to resuspend the formazan crystals. Cell viability was determined by measuring optical density at $540 \mathrm{~nm}$ using Bio-Tek ELISA multi-well plate reader (Bio-Tek Instruments Inc., Burlington, VT, USA). The cytotoxic effect of the crude venom was determined by comparing the optical density of the treated cells and the untreated cells. Phosphate buffered saline (PBS) was used as a negative control. The $\mathrm{IC}_{50}$ value was calculated from the dose-response curve.

\subsection{Cell Cycle Analysis}

Flow cytometry assessed the percentage of cellular DNA content was assessed by flow cytometry [37]. HepG2 cells were seeded in a 6-well plate at a density of $1.0 \times 10^{4}$ cells/well and incubated at $37^{\circ} \mathrm{C}$ for one day before the experiment. The cells were treated with $\mathrm{IC}_{50}$ concentration of $R$. nomadica venom for $48 \mathrm{~h}$, harvested, and fixed with $70 \%$ cold ethanol at 
$-20^{\circ} \mathrm{C}$ overnight. Fresh PBS washed the fixed cells, then stained with PI $(50 \mu \mathrm{g} / \mathrm{mL})$ in the presence of RNase A (10 $\mu \mathrm{g} / \mathrm{mL})$ and incubated for $30 \mathrm{~min}$ in the dark. The cellular DNA content was analyzed using a flow cytometer (FACSCalibur, Becton Dickinson, Franklin Lakes, NJ, USA).

\subsection{Annexin V-FITC/PI Double Staining Assay}

HepG2 cells were treated with $\mathrm{IC}_{50}$ concentration of $R$. nomadica venom for $48 \mathrm{~h}$. Both adherent and suspended cells were collected, centrifuged (1000 rpm for $5 \mathrm{~min}$ ), washed with PBS and resuspended with binding buffer $(1 \times)$. After that, the cells were stained with $4 \mu \mathrm{L}$ Annexin V-FITC and $2 \mu \mathrm{L}$ propidium iodide (PI) (Annexin V-FITC Apoptosis Detection Kit) (Abcam, Cambridge, UK) and incubated for $15 \mathrm{~min}$ at $37^{\circ} \mathrm{C}$ in the dark. The total apoptotic and necrotic cells were measured by BD FACSCalibur flow cytometer [46].

\subsection{Western Blot Analysis}

HepG2 cells were treated with $\mathrm{IC}_{50}$ concentration of $R$. nomadica venom for $48 \mathrm{~h}$, and the cell lysate was prepared in cold lysis buffer [100 mM NaCl, $10 \mathrm{mM}$ Tris, $25 \mathrm{mM}$ EDTA, 25 mM EGTA, 1\% Triton X-100, 1\% NP-40 (pH 7.4)], with 1:300 protease inhibitor cocktail (Sigma-Aldrich, St. Louis, MO, USA) and Phosphatase inhibitor cocktail Tablet (Roche Diagnostics GmbH, Mannheim, Germany). Total protein concentration was determined using the Bradford method before proceeding to the western blotting. Equal amounts $(20 \mu \mathrm{g})$ of protein samples were loaded into 12\% SDS-polyacrylamide gel and separated by Cleaver electrophoresis unit (Cleaver Scientific Ltd., Rugby, UK). They were transferred onto polyvinylidene fluoride (PVDF) membranes (Bio-Rad Laboratories, Inc., Hercules, CA, USA) for $30 \mathrm{~min}$ using a Semi-dry Electroblotter (BioRad) at $2.5 \mathrm{~A}$ and $25 \mathrm{~V}$ for $30 \mathrm{~min}$. The membrane was blocked with $5 \%$ nonfat dry milk in TBS-T for two hours at $37^{\circ} \mathrm{C}$. The membrane was incubated overnight at $4{ }^{\circ} \mathrm{C}$ with primary antibodies against BAX (1:1000, Cell Signaling Technology, Inc., Danvers, MA, USA), Bcl-2 (1:1500, Cell Signaling Technology), cleaved caspase-3 (1:750, Cell Signaling Technology), p53 (1:1000, Abcam, Cambridge, UK), and $\beta$-actin (1:5000, Sigma-Aldrich, St. Louis, MO, USA). Then, the membrane was washed three times with TBS-T and followed by incubation with the corresponding horseradish peroxidase-linked secondary antibodies (1:1000, Dako Ltd., High Wycombe, UK) for another hour at room temperature. $\beta$-actin was used as an internal reference protein. Finally, specific protein bands were visualized by a chemiluminescent detecting kit (Perkin Elmer, Waltham, MA, USA). The blot image was captured using a CCD camera-based imager (Chemi Doc imager, BioRad). The bands' intensities were then measured by densitometry using ImageLab software (Bio-Rad Laboratories, Inc., Hercules, CA, USA) $[63,64]$.

\subsection{DNA Damage Evaluation}

The apoptotic effect induced in HepG2 cells was evaluated by two different techniques that included diphenylamine (DPA) assay and DNA laddering assay.

\subsubsection{DNA Fragmentation Percentage by Diphenylamine (DPA) Assay}

DPA assay is a colorimetrical quantitative method used for assessing the DNA fragmentation caused by the treatment of HepG2 cells by $R$. nomadica venom with the concentration of $25,50 \mu \mathrm{g} / \mathrm{mL}$ for $48 \mathrm{~h}$ upon utilizing diphenylamine (DPA) reagent, which binds to deoxyribose [65]. The optical density was measured at $600 \mathrm{~nm}$ in the $S$ (fragmented DNA) and the P (intact DNA) fractions. The percentage of fragmented DNA was calculated using the formula:

$$
\text { DNA fragmentation }(\%)=[S /(S+P)] \times 100
$$




\subsubsection{DNA Laddering Assay}

Genomic DNA was extracted from HepG2 cells after the treatment with three different concentrations of $R$. nomadica venom $(25,50 \mu \mathrm{g} / \mathrm{mL})$ for $48 \mathrm{~h}$. Electrophoresis was performed in $8 \%$ agarose gel with ethidium bromide staining. Following this, the DNA in gel was visualized under UV and photographed by a digital camera (Canon U.S.A., Inc., Lake Success, NY, USA) [66].

\subsection{Hemolysis Assay}

Hemolytic activity of $R$. nomadica venom was performed on erythrocytes of humans with some modifications [56]. A blood sample was taken from a healthy adult volunteer after informed consent was obtained. The blood sample was immediately combined with anti-clot material (EDTA) and centrifuged at $5000 \mathrm{rpm}$ for $5 \mathrm{~min}$. Briefly, the erythrocytes suspension in sterile phosphate buffer saline (PBS) was received serial concentrations of the crude venom. After one hour of incubation at room temperature, the cells were centrifuged, and the supernatant was used to measure the absorbance of the liberated hemoglobin at $570 \mathrm{~nm}$. The positive control ( $100 \%$ hemolysis) and the negative control ( $0 \%$ hemolysis) were Triton X-100 and sterile phosphate buffer saline (PBS), respectively. The following equation measured the hemolysis percentage for each sample:

$$
\text { Hemolysis }(\%)=[(\text { AS }- \text { A) } /(\text { AP.C }- \text { AN.C }] \times 100
$$

where AS is the mean of absorbance of sample, AN.C is the mean of absorbance of negative control, and AP.C is the mean of absorbance of positive control.

\subsection{Statistical Analysis}

All experiments are achieved in triplicate. The values are shown as mean value $\pm \mathrm{SE}$ and data were analyzed using paired Student's t-test and one-way ANOVA followed by Tukey's test. Statistical significance was assessed by $p<0.05$.

\section{Conclusions}

In conclusion, our findings highlighted the anti-proliferative effect of $R$. nomadica venom and clearly showed that the venom extract could induce apoptosis in vitro. Therefore, these data might provide a starting point for the research on using $R$. nomadica venom in the treatment of cancer and hepatocellular carcinoma in particular. However, future investigations may be conducted to investigate the anticancer activities of $R$. nomadica venom in vivo and to characterize and identify the bioactive peptides that exert anticancer activity. Further, future experiments will be planned to investigate cytoprotective properties of $R$. nomadica venom on $\mathrm{H}_{2} \mathrm{O}_{2}$-treated cells in vitro and in vivo models. Moreover, protein and gene expressions of the antioxidative enzymes and oxidative biomarkers for cell membrane lipid peroxidation will be analyzed upon treatment with $R$. nomadica venom. Such experimental work may reveal in detail the redox activity of $R$. nomadica venom.

Author Contributions: Conceptualization, M.M.T.; A.H.A.A. and N.E.; methodology, M.M.T.; A.H.A.A.; N.E.; E.F. and F.A.; software and validation, M.M.T.; A.H.A.A. and E.F.; formal analysis investigation, resources, data curation, M.M.T.; A.H.A.A. and N.E.; writing-original draft preparation M.M.T. and N.E.; writing-review and editing, M.M.T. and F.A.; project administration, M.M.T. and A.H.A.A.; funding acquisition, F.A.; E.F. and N.E. All authors have read and agreed to the published version of the manuscript.

Funding: Taif University Researchers Supporting Project number (TURSP-2020/222), Taif University, Taif, Saudi Arabia.

Institutional Review Board Statement: This study was performed according to the guidelines of the US National Institute of Health (NIH Publication No. 85.23, revised 1985) guides and has been reviewed and approved by the animal care and use according to Zoology Department, Faculty of Science, Port Said University (approved duration: 2020 to 2021). 
Informed Consent Statement: A blood sample was taken from a healthy adult volunteer after informed consent was obtained.

Data Availability Statement: The data presented in this study are available on request from the corresponding author.

Acknowledgments: The authors would like to thank the Deanship of Scientific Research at Taif University for funding this work through Taif University Researchers Supporting Project number (TURSP-2020/222), Taif University, Taif, Saudi Arabia.

Conflicts of Interest: The authors declare no conflict of interest.

Sample Availability: Samples of the compounds are available from the authors.

\section{References}

1. Villanueva, A. Hepatocellular Carcinoma. N. Engl. J. Med. 2019, 380, 1450-1462. [CrossRef] [PubMed]

2. Ibrahim, A.S.; Khaled, H.M.; Mikhail, N.N.; Baraka, H.; Kamel, H. Cancer incidence in egypt: Results of the national populationbased cancer registry program. J. Cancer Epidemiol. 2014, 2014, 437971. [CrossRef] [PubMed]

3. Ziada, D.H.; El Sadany, S.; Soliman, H.; Abd-Elsalam, S.; Salama, M.; Hawash, N.; Selim, A.; Hamisa, M.; Elsabagh, H.M. Prevalence of hepatocellular carcinoma in chronic hepatitis C patients in Mid Delta, Egypt: A single center study. J. Egypt. Natl. Cancer Inst. 2016, 28, 257-262. [CrossRef]

4. Chen, K.-W.; Ou, T.-M.; Hsu, C.-W.; Horng, C.-T.; Lee, C.-C.; Tsai, Y.-Y.; Tsai, C.-C.; Liou, Y.-S.; Yang, C.-C.; Hsueh, C.-W.; et al Current systemic treatment of hepatocellular carcinoma: A review of the literature. World J. Hepatol. 2015, 7, 1412-1420. [CrossRef] [PubMed]

5. Yim, H.J.; Suh, S.J.; Um, S.H. Current management of hepatocellular carcinoma: An Eastern perspective. World J. Gastroenterol. 2015, 21, 3826-3842. [CrossRef]

6. Le Grazie, M.; Biagini, M.R.; Tarocchi, M.; Polvani, S.; Galli, A. Chemotherapy for hepatocellular carcinoma: The present and the future. World J. Hepatol. 2017, 9, 907-920. [CrossRef] [PubMed]

7. Yu, Y.; Feng, M. Radiotherapy for Hepatocellular Carcinoma. Semin. Radiat. Oncol. 2018, 28, 277-287. [CrossRef]

8. Goldstein, J.; Steiner, U.K. Ecological drivers of jellyfish blooms-The complex life history of a 'well-known' medusa (Aurelia aurita). J. Anim. Ecol. 2020, 89, 910-920. [CrossRef]

9. Needleman, R.K.; Neylan, I.P.; Erickson, T.B. Environmental and Ecological Effects of Climate Change on Venomous Marine and Amphibious Species in the Wilderness. Wilderness Environ. 2018, 29, 343-356. [CrossRef]

10. Thé, J.; Barroso, H.d.S.; Mammone, M.; Viana, M.; Batista Melo, C.S.; Mies, M.; Banha, T.N.S.; Morandini, A.C.; Rossi, S.; Soares, M.d.O. Aquaculture facilities promote populational stability throughout seasons and increase medusae size for the invasive jellyfish Cassiopea andromeda. Mar. Environ. Res. 2020, 162, 105161. [CrossRef]

11. Ayed, Y.; Dellai, A.; Ben Mansour, H.; Bacha, H.; Abid, S. Analgesic and antibutyrylcholinestrasic activities of the venom prepared from the Mediterranean jellyfish Pelagia noctiluca (Forsskal, 1775). Ann. Clin. Microbiol. Antimicrob. 2012, 11, 15. [CrossRef] [PubMed]

12. Kang, C.; Munawir, A.; Cha, M.; Sohn, E.-T.; Lee, H.; Kim, J.-S.; Yoon, W.D.; Lim, D.; Kim, E. Cytotoxicity and hemolytic activity of jellyfish Nemopilema nomurai (Scyphozoa: Rhizostomeae) venom. Comp. Biochem. Physiol. Toxicol. Pharmacol. 2009, 150, 85-90. [CrossRef] [PubMed]

13. Ramasamy, S.; Isbister, G.K.; Seymour, J.E.; Hodgson, W.C. Pharmacologically distinct cardiovascular effects of box jellyfish (Chironex fleckeri) venom and a tentacle-only extract in rats. Toxicol. Lett 2005, 155, 219-226. [CrossRef] [PubMed]

14. Weston, A.J.; Chung, R.; Dunlap, W.C.; Morandini, A.C.; Marques, A.C.; Moura-da-Silva, A.M.; Ward, M.; Padilla, G.; da Silva, L.F.; Andreakis, N.; et al. Proteomic characterisation of toxins isolated from nematocysts of the South Atlantic jellyfish Olindias sambaquiensis. Toxicon Off. J. Int. Soc. Toxinology 2013, 71, 11-17. [CrossRef] [PubMed]

15. Yu, H.; Liu, X.; Xing, R.; Liu, S.; Li, C.; Li, P. Radical scavenging activity of protein from tentacles of jellyfish Rhopilema esculentum. Bioorg. Med. Chem. Lett. 2005, 15, 2659-2664. [CrossRef] [PubMed]

16. Leone, A.; Lecci, R.M.; Durante, M.; Piraino, S. Extract from the Zooxanthellate Jellyfish Cotylorhiza tuberculata Modulates Gap Junction Intercellular Communication in Human Cell Cultures. Mar. Drugs 2013, 11, 1728-1762. [CrossRef] [PubMed]

17. Mariottini, G.L. The Role of Cnidaria in Drug Discovery. In The Cnidaria, Past, Present and Future: The World of Medusa and Her Sisters; Goffredo, S., Dubinsky, Z., Eds.; Springer International Publishing: Cham, Switzerland, 2016; pp. 653-668. [CrossRef]

18. Fulda, S. Targeting apoptosis for anticancer therapy. Intracellular Signaling and Response to Anti-Cancer Therapy. Semin. Cancer Biol. 2015, 31, 84-88. [CrossRef]

19. Pfeffer, C.M.; Singh, A.T.K. Apoptosis: A Target for Anticancer Therapy. Int. J. Mol. Sci. 2018, 19, 448. [CrossRef]

20. Verena, J. The Intrinsic Apoptosis Pathways as a Target in Anticancer Therapy. Curr. Pharm. Biotechnol. 2012, 13, $1426-1438$.

21. Doonan, F.; Cotter, T.G. Morphological assessment of apoptosis. Methods 2008, 44, 200-204. [CrossRef]

22. Häcker, G. The morphology of apoptosis. Cell Tissue Res. 2000, 301, 5-17. [CrossRef] [PubMed]

23. Saraste, A.; Pulkki, K. Morphologic and biochemical hallmarks of apoptosis. Cardiovasc. Res. 2000, 45, 528-537. [CrossRef] 
24. Cuiping, L.; Pengcheng, L.; Jinhua, F.; Rongfeng, L.; Huahua, Y. Cytotoxicity of the venom from the nematocysts of jellyfish Cyanea nozakii Kishinouye. Toxicol. Ind. Health 2012, 28, 186-192. [CrossRef] [PubMed]

25. Kawabata, T.; Lindsay, D.J.; Kitamura, M.; Konishi, S.; Nishikawa, J.; Nishida, S.; Kamio, M.; Nagai, H. Evaluation of the bioactivities of water-soluble extracts from twelve deep-sea jellyfish species. Fish Sci. 2013, 79, 487-494. [CrossRef]

26. Ayed, Y.; Sghaier, R.M.; Laouini, D.; Bacha, H. Evaluation of anti-proliferative and anti-inflammatory activities of Pelagia noctiluca venom in Lipopolysaccharide/Interferon- $\gamma$ stimulated RAW264.7 macrophages. Biomed. Pharmacother. 2016, 84, 1986-1991. [CrossRef] [PubMed]

27. Morabito, R.; Condello, S.; Currò, M.; Marino, A.; Ientile, R.; La Spada, G. Oxidative stress induced by crude venom from the jellyfish Pelagia noctiluca in neuronal-like differentiated SH-SY5Y cells. Toxicol. In Vitro 2012, 26, 694-699. [CrossRef]

28. Mirshamsi, M.R.; Omranipour, R.; Vazirizadeh, A.; Fakhri, A.; Zangeneh, F.; Mohebbi, G.H.; Seyedian, R.; Pourahmad, J. Persian Gulf Jellyfish (Cassiopea andromeda) Venom Fractions Induce Selective Injury and Cytochrome C Release in Mitochondria Obtained from Breast Adenocarcinoma Patients. Asian Pac. J. Cancer Prev. 2017, 18, 277-286. [CrossRef]

29. Ayed, Y.; Boussabbeh, M.; Zakhama, W.; Bouaziz, C.; Abid, S.; Bacha, H. Induction of cytotoxicity of Pelagia noctiluca venom causes reactive oxygen species generation, lipid peroxydation induction and DNA damage in human colon cancer cells. Lipids Health Dis. 2011, 10, 232. [CrossRef]

30. Edelist, D.; Guy-Haim, T.; Kuplik, Z.; Zuckerman, N.; Nemoy, P.; Angel, D.L. Phenological shift in swarming patterns of Rhopilema nomadica in the Eastern Mediterranean Sea. J. Plankton Res. 2020, 42, 211-219. [CrossRef]

31. Jafari, H.; Honari, H.; Zargan, J.; Jahromi, S.T. Identification and hemolytic activity of jellyfish (Rhopilema sp., Scyphozoa: Rhizostomeae) venom from the Persian Gulf and Oman Sea. Biodiversitas J. Biol. Divers. 2019, 20, 1228-1232. [CrossRef]

32. Yahia, M.N.D.; Yahia, O.K.-D.; Gueroun, S.K.M.; Aissi, M.; Deidun, A.; Fuentes, V.; Piraino, S. The invasive tropical scyphozoan Rhopilema nomadica Galil, 2013, 1990 reaches the Tunisian coast of the Mediterranean Sea. BioInvasions Rec. 2013, 2, 319-323. [CrossRef]

33. Balistreri, P.; Spiga, A.; Deidun, A.; Gueroun, S.K.; Yahia, M.N.D. Further spread of the venomous jellyfish Rhopilema nomadica Galil, Spannier \& Ferguson, 1990 (Rhizostomeae, Rhizostomatidae) in the western Mediterranean. BioInvasions Rec. 2017, 6, 19-24. [CrossRef]

34. El-Regal, M.A.A.; Temraz, T.A. Blooming of the Nomad Jelly Fish Rhopilema Nomadica along the Egyptian Mediterranean Coasts 1. In Proceedings of the International Jellyfish Bloom Symposium, Barcelona, Spain, 30 May-3 June 2016.

35. Lazcano-Pérez, F.; Zavala-Moreno, A.; Rufino-González, Y.; Ponce-Macotela, M.; García-Arredondo, A.; Cuevas-Cruz, M.; Gómez-Manzo, S.; Marcial-Quino, J.; Arreguín-Lozano, B.; Arreguín-Espinosa, R. Hemolytic, anticancer and antigiardial activity of Palythoa caribaeorum venom. J. Venom. Anim. Toxins Trop. Dis. 2018, 24, 1-7. [CrossRef] [PubMed]

36. Maduraiveeran, H.; Raja, K.; Chinnasamy, A. Antiproliferative and antioxidant properties of nematocysts crude venom from jellyfish Acromitus flagellatus against human cancer cell lines. Saudi J. Biol. Sci. 2021, 28, 1954-1961. [CrossRef]

37. Lee, H.; Bae, S.K.; Kim, M.; Pyo, M.J.; Kim, M.Y.S.; Won, C.-K.; Yoon, W.D.; Han, C.H.; Kang, C.; Kim, E. Anticancer Effect of Nemopilema nomurai Jellyfish Venom on HepG2 Cells and a Tumor Xenograft Animal Model. Evid. Based Complement. Altern. Med. 2017, 2017, 2752716. [CrossRef]

38. Choudhary, I.; Lee, H.; Pyo, M.J.; Heo, Y.; Chae, J.; Yum, S.S.; Kang, C.; Kim, E. Proteomic Investigation to Identify Anticancer Targets of Nemopilema nomurai Jellyfish Venom in Human Hepatocarcinoma HepG2 Cells. Toxins 2018, 10, 194. [CrossRef]

39. Helmholz, H.; Ruhnau, C.; Schütt, C.; Prange, A. Comparative study on the cell toxicity and enzymatic activity of two northern scyphozoan species Cyanea capillata (L.) and Cyanea lamarckii (Péron \& Léslieur). Toxicon 2007, 50, 53-64. [CrossRef] [PubMed]

40. Lee, H.; Pyo, M.J.; Bae, S.K.; Heo, Y.; Choudhary, I.; Hwang, D.; Yang, H.; Kim, J.; Chae, J.; Han, C.H.; et al. Nemopilema nomurai jellyfish venom exerts an anti-metastatic effect by inhibiting Smad- and NF- $\mathrm{kB}$-mediated epithelial-mesenchymal transition in HepG2 cells. Sci. Rep. 2018, 8, 2808. [CrossRef]

41. Lassen, S.; Helmholz, H.; Ruhnau, C.; Prange, A. A novel proteinaceous cytotoxin from the northern Scyphozoa Cyanea capillata (L.) with structural homology to cubozoan haemolysins. Toxicon 2011, 57, 721-729. [CrossRef]

42. Remigante, A.; Costa, R.; Morabito, R.; La Spada, G.; Marino, A.; Dossena, S. Impact of Scyphozoan Venoms on Human Health and Current First Aid Options for Stings. Toxins 2018, 10, 133. [CrossRef]

43. Brinkman, D.L.; Konstantakopoulos, N.; McInerney, B.V.; Mulvenna, J.; Seymour, J.E.; Isbister, G.K.; Hodgson, W.C. Chironex fleckeri (Box Jellyfish) Venom Proteins: Expansion of a Cnidarian Toxin Family that Elicits Variable Cytolytic and Cardiovascular Effects. J. Biol. Chem. 2014, 289, 4798-4812. [CrossRef]

44. Balamurugan, E.; Ramesh Kumar, D.; Menon, V. Proapoptotic Effect of Chrysaora Quinquecirrha (Sea Nettle) Nematocyst Venom Peptide in HEp 2 and HeLa Cells. Eur. J. Sci. Res. 2009, 35, 355-367.

45. Sun, L.-K.; Yoshii, Y.; Hyodo, A.; Tsurushima, H.; Saito, A.; Harakuni, T.; Li, Y.-P.; Nozaki, M.; Morine, N. Apoptosis induced by box jellyfish (Chiropsalmus Quadrigatus) toxin in glioma and vascular endothelial cell lines. Toxicon 2002, 40, 441-446. [CrossRef]

46. Ha, S.-H.; Jin, F.; Kwak, C.-H.; Abekura, F.; Park, J.-Y.; Park, N.G.; Chang, Y.-C.; Lee, Y.-C.; Chung, T.-W.; Ha, K.-T.; et al. Jellyfish extract induces apoptotic cell death through the p38 pathway and cell cycle arrest in chronic myelogenous leukemia K562 cells. PeerJ 2017, 5, e2895. [CrossRef] [PubMed]

47. Qu, X.; Xia, X.; Lai, Z.; Zhong, T.; Li, G.; Fan, L.; Shu, W. Apoptosis-like cell death induced by nematocyst venom from Chrysaora helvola Brandt jellyfish and an in vitro evaluation of commonly used antidotes. Comp. Biochem. Physiol. Part C Toxicol. Pharmacol. 2016, 180, 31-39. [CrossRef] [PubMed] 
48. Goldar, S.; Khaniani, M.S.; Derakhshan, S.M.; Baradaran, B. Molecular mechanisms of apoptosis and roles in cancer development and treatment. Asian Pac. J. Cancer Prev. 2015, 16, 2129-2144. [CrossRef] [PubMed]

49. Nikoletopoulou, V.; Markaki, M.; Palikaras, K.; Tavernarakis, N. Crosstalk between apoptosis, necrosis and autophagy. Biochim. Et Biophys. Acta BBA Mol. Cell Res. 2013, 1833, 3448-3459. [CrossRef]

50. Ghobrial, I.M.; Witzig, T.E.; Adjei, A.A. Targeting apoptosis pathways in cancer therapy. CA Cancer J. Clin. 2005, 55, 178-194. [CrossRef]

51. Kim, R. Recent advances in understanding the cell death pathways activated by anticancer therapy. Cancer 2005, 103, 1551-1560. [CrossRef] [PubMed]

52. Elmore, S. Apoptosis: A Review of Programmed Cell Death. Toxicol. Pathol. 2007, 35, 495-516. [CrossRef]

53. Hengartner, M.O. The biochemistry of apoptosis. Nature 2000, 407, 770-776. [CrossRef] [PubMed]

54. Sankari, S.L.; Masthan, K.M.K.; Babu, N.A.; Bhattacharjee, T.; Elumalai, M. Apoptosis in cancer-An update. Asian Pac. J. Cancer Prev. 2012, 13, 4873-4878. [CrossRef]

55. Chi, S.-W. Structural insights into the transcription-independent apoptotic pathway of p53. BMB Rep. 2014, 47, 167-172. [CrossRef] [PubMed]

56. Torres, M.; Aguilar, M.B.; Falcón, A.; Sánchez, L.; Radwan, F.F.Y.; Burnett, J.W.; Heimer-de la Cotera, E.P.; Arellano, R.O. Electrophysiological and hemolytic activity elicited by the venom of the jellyfish Cassiopea xamachana. Toxicon 2001, 39, 1297-1307. [CrossRef]

57. Bloom, D.; Burnett, J.; Alderslade, P. Partial purification of box jellyfish (Chironex fleckeri) nematocyst venom isolated at the beachside. Toxicon Off. J. Int. Soc. Toxinology 1998, 36, 1075-1085. [CrossRef]

58. Marino, A.; Morabito, R.; Pizzata, T.; La Spada, G. Effect of various factors on Pelagia noctiluca (Cnidaria, Scyphozoa) crude venom-induced haemolysis. Comp. Biochem. Physiol. A Mol. Integr. Physiol. 2008, 151, 144-149. [CrossRef] [PubMed]

59. Bradford, M.M. A rapid and sensitive method for the quantitation of microgram quantities of protein utilizing the principle of protein-dye binding. Anal. Biochem. 1976, 72, 248-254. [CrossRef]

60. Laemmli, U.K. Cleavage of structural proteins during the assembly of the head of bacteriophage T4. Nature 1970, 227, 680-685. [CrossRef]

61. Sebeka, A.A.H.; Osman, A.M.A.; Sayed, I.; Bahanasawy, M.; Tantawy, M. Synthesis and Antiproliferative Activity of Novel Neocryptolepine-Hydrazides Hybrids. J. Appl. Pharm. Sci. 2017, 7, 9-15. [CrossRef]

62. Tantawy, M.A.; Sroor, F.M.; Mohamed, M.F.; El-Naggar, M.E.; Saleh, F.M.; Hassaneen, H.M.; Abdelhamid, I.A. Molecular Docking Study, Cytotoxicity, Cell Cycle Arrest and Apoptotic Induction of Novel Chalcones Incorporating Thiadiazolyl Isoquinoline in Cervical Cancer. Anticancer Agents Med. Chem. 2020, 20, 70-83. [CrossRef]

63. Sambrook, J.; Fritsch, E.F.; Maniatis, T. Molecular Cloning: A Laboratory Manual, 2nd ed.; Cold Spring Harbor Laboratory Press: New York, NY, USA, 1989; ISBN 0879693096.

64. Burnette, W.N. "Western blotting": Electrophoretic transfer of proteins from sodium dodecyl sulfate-polyacrylamide gels to unmodified nitrocellulose and radiographic detection with antibody and radioiodinated protein A. Anal. Biochem. 1981, 112, 195-203. [CrossRef]

65. Zhao, Y.; Xiang, S.; Dai, X.; Yang, K. A simplified diphenylamine colorimetric method for growth quantification. Appl. Microbiol. Biotechnol. 2013, 97, 5069-5077. [CrossRef]

66. Gong, J.P.; Traganos, F.; Darzynkiewicz, Z. A Selective Procedure for DNA Extraction from Apoptotic Cells Applicable for Gel Electrophoresis and Flow Cytometry. Anal. Biochem. 1994, 218, 314-319. [CrossRef] 